Pak. j. sci. ind. res. Ser. B: biol. sci. 2018 61B(2) 115-120

\title{
Review
}

\section{A Review on Rangeland Management in Pakistan, Bottlenecks and Recommendations}

\author{
Muhammad Jamila ${ }^{\mathrm{a}}$, Muhammad Mansoor ${ }^{\mathrm{a} *}$, Fawad Anwar ${ }^{\mathrm{a}}$, \\ Sher Muhammad ${ }^{b}$ and Aftab Ahmed Awan ${ }^{a}$ \\ ${ }^{a}$ Arid Zone Research Centre (AZRC, PARC), Dera Ismail Khan-29050, Pakistan \\ ${ }^{b}$ National Agricultural Research Center, Islamabad, Pakistan
}

(received August 25, 2016; revised March 30, 2017; accepted May 2, 2017)

\begin{abstract}
Role of rangelands in the livelihoods improvement of rural communes' is pivotal, through animal rearing, obtaining versatile products and services. Rangelands play key role in maintenance of agroecosystem and preservation of biodiversity in the country by improving infiltration rate, leading thereby a sustainable water flow in the down streams and reducing soil erosion. However, due to increased population pressure there is analogous increase in the demand for food, forage and other resources. In addition rangelands provide wildlife and fish habitat and recreation spots. Keeping in view the current global climate change scenario the government has given high priority to rangelands management, hence the concentration of the politicians and policy makers is to focus on the sustainable rangeland development and management. The article deals first with the importance of range management, then discusses rangelands problems of Pakistan, causes of degradation of rangelands, human factors contributing to range degradation and finally recommendations are discussed.
\end{abstract}

Keywords: Pakistan, rangeland, livestock, management, biodiversity

\section{Introduction}

Total area of Pakistan, including northern areas and Azad Jammu and Kashmir, is 87.98 million ha. About 50.88 million ha, constituting almost $58 \%$ of the area, are rangelands (Afzal et al., 2008). Pakistan is situated between $24^{\circ} 37^{\prime} \mathrm{N}$ and $61^{\circ} 75^{\prime} \mathrm{E}$. The weather conditions are arid with small amount of rains and dampness and high solar radiation over the majority of the parts of the country. The majority of the areas get less than $200 \mathrm{~mm}$ precipitation per annum with the exception of the high altitude northern mountain range, which receive about $500 \mathrm{~mm}$. The rainfall supply varies greatly, $60 \%$ of rainfall in Sindh and Punjab province strikes during the monsoon period i.e., from July to the begining of September. Balochistan and northern regions get maximum rainfall from October to March (FAO, 1987). The July 2006 citizenry approximate as outlined by the World Fact Book was 165, 803, 5650 with growing rate of $2.09 \%$. The overall region of Pakistan, along with Azad Kashmir, is $88 \mathrm{M} / \mathrm{ha}$. The primary land utilisation in Pakistan is agriculture, livestock productivity and forestry. As a very limited work has been done so far on rangelands development, latest study found was of

*Author for correspondence; E-mail: joyadkpk@gmail.com
2012. Hence, it was decided to review all earlier work done with focus on bottlenecks and for formulation of recommendations. Approximately $5 \mathrm{M} /$ ha of the cultivation region ( $24 \%$ of entire area) is rain fed whereas $16 \mathrm{M} / \mathrm{ha}$ is irrigated. Afzal et al. (2008) study indicated that around $60 \%(45.2 \mathrm{M} / \mathrm{ha})$ of the overall region is rangelands. The majority of these rangelands gets lower than $200 \mathrm{~mm}$ rainfall, and situated on rocky grounds, deserts, and rough topography. Thus, production is very less and it is impossible to use them for continuous farming purpose. In spite of this, these kinds of rangelands somewhat hold up 93.5 M livestock throughout the summer season (Afzal et al., 2008).

As far as the distribution of rangelands in province is concerned, Khyber Pakhtunkhwa contains 5.6\% rangelands of its total land area while Balochistan, Punjab and Sindh have $93 \%, 4.7 \%$ and $60 \%$ rangelands of their total land areas, respectively, while about 6 million hectares rangelands are under the control of forest department. Grazing beyond carrying capacity over vast areas of rangelands has gradually put too much pressure on rangelands, vegetation and their inhabitants, like wild life, livestock and pastoral groups. The big contributory aspects are increasing in human and 
livestock populations. This has led to a development of dry land production on marginal plains to fulfill the growing requirements for human food crops, and clipping of shrubs and plants for domestic energy resources utilisation. Chrysopogon aucheri and Cymbopogon jwarancusa are the dominant bunchgrasses in grassland ecosystems of upland Balochistan. These grasses are found on a wide variety of soils over a wide range of elevations, and play an important role in ecosystem level processes (Ahmad et al., 2000; Umrani et al., 1995; FAO, 1987; Aleem, 1980). Agriculture is the backbone of the overall economy of Pakistan. Around $75-80 \%$ of the residential of Pakistan depends upon agriculture which adds $30 \%$ to the gross domestic product. Incorporated agricultural methods are used and deficiency of feed is a significant reducing aspect in livestock production. Livestock is a significant mean of income in irrigated, arid, semiarid, and rain-fed regions of Pakistan. Currently, sheeps and goats get about $60 \%$ of feed from rangeland areas (Mahmood and Rodriquez, 1991), whilst horses, donkeys and camels get about half of their feed demands from rangeland areas. In Balochistan, $90 \%$ livestock feed is taken from pastures (FAO, 1987). Overall region under cultivated fodder crops in Pakistan is about $2.7 \mathrm{M} / \mathrm{ha}$ with an output of $53 \mathrm{M} /$ tonnes of green fodder (Table 1). Normal forage yield per hectare are around 19.4 tonnes. In spite of the higher levels of production, there exists shortage of meat, milk, butter and other dairy foods in the country. The consumption of meat is

Table 1. Area under different fodder crops and total forage yields/ha

\begin{tabular}{lll}
\hline \hline Crops & $\begin{array}{l}\text { Area } \\
(, 000 \text { ha })\end{array}$ & $\begin{array}{l}\text { Average yields } \\
(\mathrm{t} / \mathrm{ha})\end{array}$ \\
\hline Sorghum & 515.1 & 14.8 \\
Millets & 105.1 & 7.2 \\
Guar & 311.4 & 11.4 \\
Maize & 48.1 & 19.6 \\
Moth & 1.4 & 12.1 \\
Other Summer fodder & 495.3 & 33.4 \\
Berseem & 820.1 & 27.7 \\
Lucerne & 152.2 & 32 \\
Shaftal & 32.6 & 24.8 \\
Oats & 0.1 & 3.6 \\
Rape and Mustard & 23.4 & 16.7 \\
Other Winter fodder & 209.2 & 21.7 \\
Total & 274.1 & 19.4 \\
\hline \hline
\end{tabular}

low as $4-5 \mathrm{~kg} / \mathrm{head} / \mathrm{year}$, and total protein utilisation is $45.8 \mathrm{~g} / \mathrm{head} / \mathrm{day}$, in which just $12.2 \mathrm{~g}$ originates from animal protein.

Rangelands are the major land use in Khyber Pakhtunkhwa which makes up $26.5 \%$ of the total land area in the province. By definition, rangelands are those areas which by reason of physical limitation, low and erratic precipitation, rough topography, poor drainage or extreme temperature are unsuited to cultivation and which are source of forage for free ranging native and domestic animals, as well as a source of wood products, water and wildlife. Soil upon which the indigenous native is mainly grasses, grass like plants, forbs, or shrubs and handled like a natural ecosystem is called Rangeland. Pakistan has a total area of approx. 88 million hectare, about $65 \%$ of which consists of rangelands. Five different types of range ecological zones (Subalpine and temperate, Sub-tropical humid, Sub-tropical sub humid, Tropical arid and semi-arid deserts plains, and Mediterranean) are found in Pakistan. These rangelands are the major feed-source of about 97 million heads of livestock.

Rangelands are distinguished from pasture lands because they grow primarily native vegetation, rather than plants established by humans. Rangelands are also managed principally with extensive practices such as managed livestock grazing and prescribed fire rather than more intensive agricultural practices of seeding, irrigation, and the use of fertilizers. Grazing is an important use

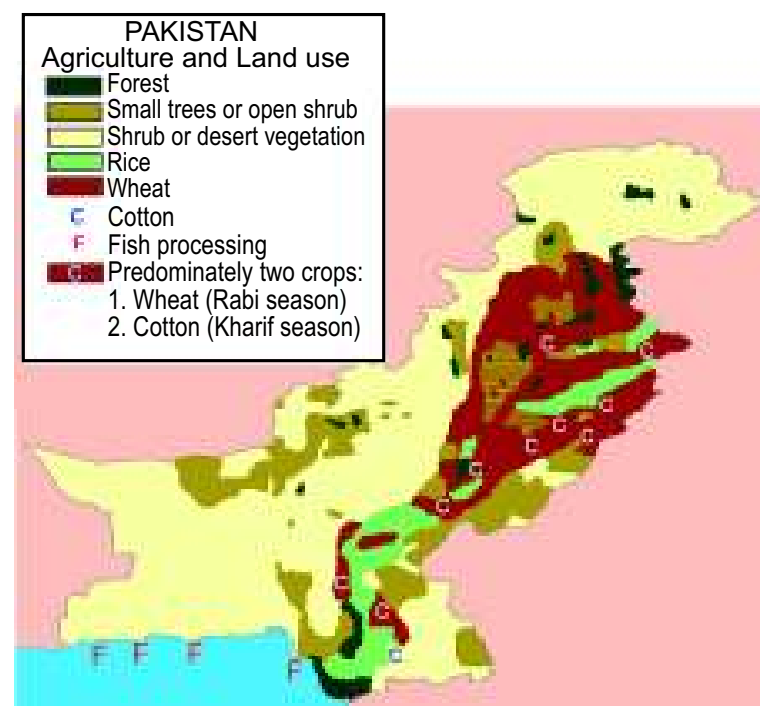

Fig. 1. Land use patterns of Pakistan. 
of rangelands but the term "rangeland" is not synonymous with "grazing lands". There are areas of rangeland that are not grazed and there are grazed areas that are not rangelands. Livestock grazing can be used to manage rangelands by harvesting forage to produce livestock, changing plant composition or reducing fuel loads. Fire is also an important regulator of range vegetation, whether set by humans or resulting from lightening. Fires tend to reduce the abundance of woody plants and promote herbaceous plants including grasses, and grass-like plants. The suppression or reduction of periodic wildfires from desert shrub lands, savannas, or woodlands frequently invites the dominance of trees and shrubs to the near exclusion of grasses and forbs.

Problems of rangelands in Pakistan. The main problem of rangelands in Pakistan is the shortage of rangeland grasses due to which the animal production and productivity are far below the optimal levels. People living there are poor and are facing difficulties in meeting their daily essential needs of life. Due to low production of forage species, animal nutrition is the biggest problem of the livestock keepers. The feed available from arable rangelands is of low quality. The fodder available in

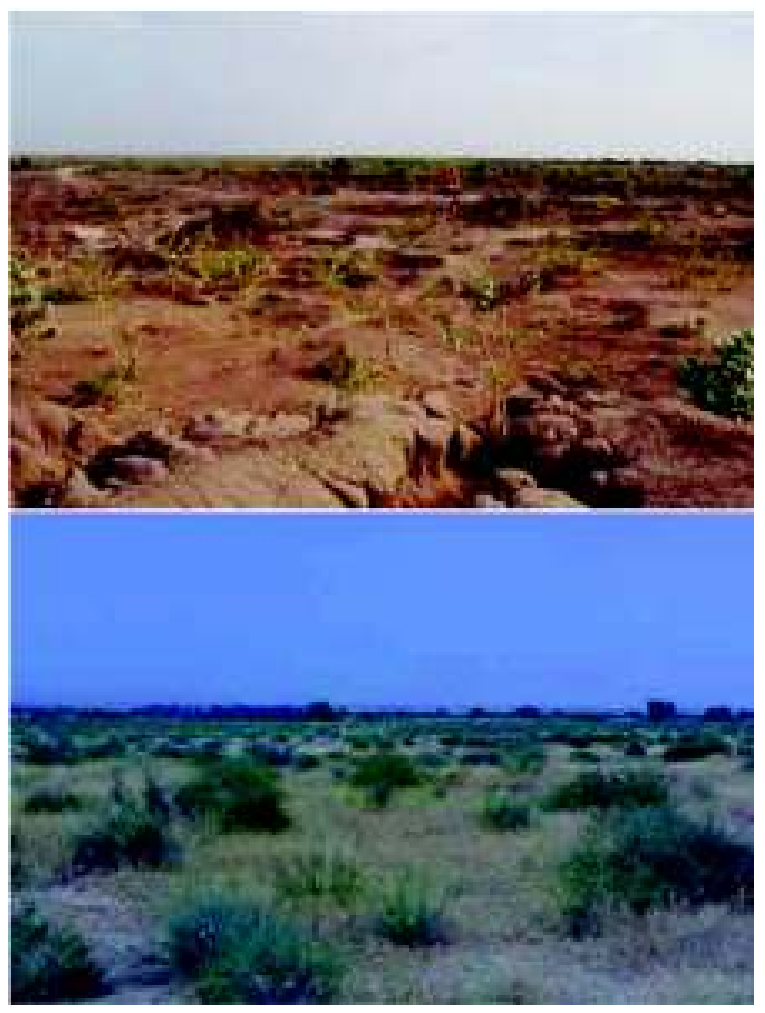

Fig. 2. Degraded rangelands. the market is of high price and people are unable to afford. Even some people do not have their own rangelands and croplands to meet the demand of their forage so they have to buy forage for their livestock the whole year which is very difficult for the poor people. Rangeland productivity in Balochistan is substantially affected due to non-existence of grazing management practices, low and erratic rainfall distribution, and over exploitation of natural resources. Most of the rangelands in Balochistan lie within the arid and semi-arid climatic zones. These ranges are degrading very rapidly in terms of biomass production and desirable range species. Most of the rangelands belong either to tribes or open grazing rangelands. The Pastoralists are facing number of challenges but the major one is shortage of feed and forage for livestock particularly in winter months (Ahmad et al., 2009; Bano et al., 2009). To solve the problems of rangelands in Pakistan, following initiative measures should be adopted:

- Establishment of seed multiplication programme

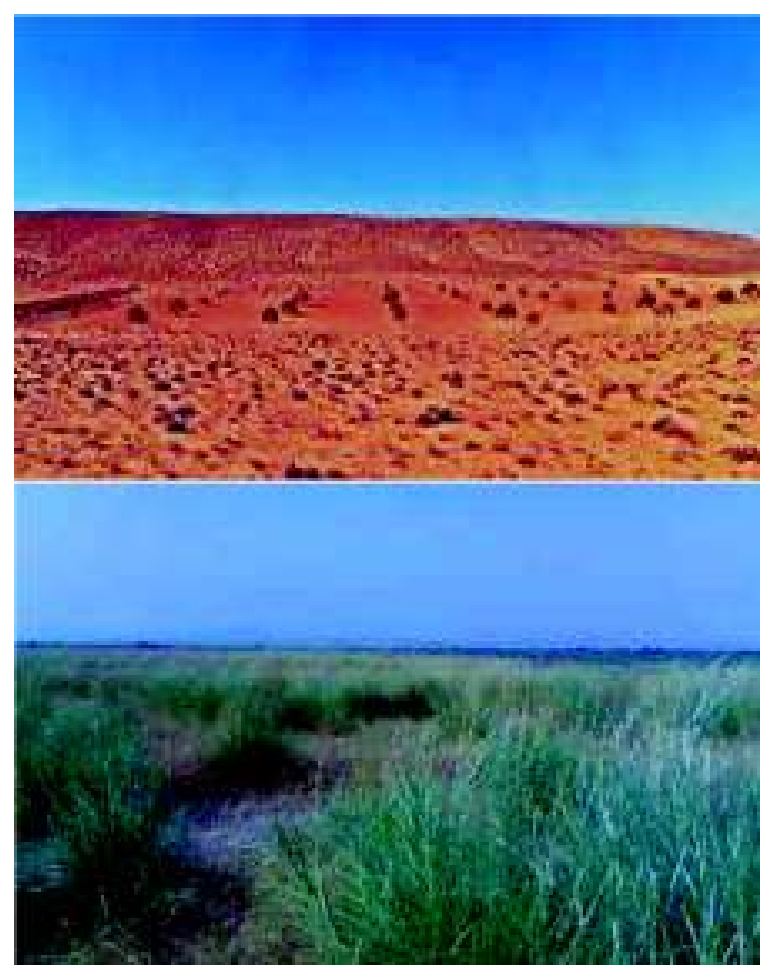

Fig. 3. A view of seeded and unseeded area of Rakh Shadan Lund rangeland (Sarfraz et al., 2012; Islam et al., 2008; Hussain and Durrani, 2007). 
- Selection of suitable grass, fodder trees and shrub species with a high nutritional value

- Re-sowing of areas and fertilization

- Plant introduction trials

- Proper grazing management

A case study was taken in Malakand Social Forestry Project (1988) through which a survey was conducted in fifty one villages of the Malakand Agency. In every village household head was interviewed. The livestock resources were found; the grazing systems were determined, the fodder and fuel collection methods and ways with quality were gathered and information about the perceptions of forestry and range management were recorded. Recommendations were given for the deteriorated condition of Malakand hills. Malakand Social Forestry Project (1988) was surveyed in three villages of Malakand Agency (Jalala, Mekhband and Baz Dera). The survey was carried out through questionnaire. These three villages were selected out of twenty villages where the project started its activities. Results of the survey were used for recommendations. About 707 household heads were interviewed. About three livestock units per household were found in Jalala village while in Mekhband and Baz Dera twenty nine and thirty nine livestock units were found, respectively. In recommendations, four grazing systems were suggested:

a. Strengthening the village development Committees.

b. Silage making to conserve the grasses for rainy days.

c. Improvement in production of the communal rangeland.
Causes of degradation of rangelands in Pakistan. Degradation of rangeland is raising due to (i) no emphasis on grazing management programmes and (ii) removing of vegetation for wood fuel without any obvious influence of rangeland possession. The main factors of rangelands degradation are change in the species compositions, loss in range biodiversity, less plant cover, decrease in biomass productions and less small ruminants productivity with soil erosion (Ahmad and Ehsan, 2012). Overgrazing, drought, erosion, and human induced stresses caused severe degradation of rangelands in Balochistan (Islam et al., 2008; Hussain and Durrani, 2007). Rangeland degradation is occurring as a result of no grazing management plans, removal of vegetation for fuel wood and no clear authority of rangeland ownership. The major indicators of rangelands degradation are shift in species composition, loss of range biodiversity, reduction in biomass production, less plant cover, low small ruminant productivity, and soil erosion (Ahmad and Ehsan, 2012). Perennial grasses and palatable shrub species are confined to only in some protected forest areas. The degradation of rangeland in Balochistan is site specific and depends on the existing vegetation, grazing pressure, grazing accessibility, human population, availability of stock water, and tribal conflicts (Ahmad and Islam, 2011).

However, the impact of rangeland degradation on other services like carbon sequestration, conservation of plant and wildlife biodiversity, water harvesting and spreading, infiltration, and many other environmental services are either not monitored, documented or disseminated the information among the various sectors of the society. Recovery of range vegetation at some sites in Balochistan

Table 2. Animal units (A.U.) feeding on rangelands in Pakistan (in million)

\begin{tabular}{llllll}
\hline \hline Livestock & $\begin{array}{c}\text { Livestock population } \\
\text { 2007-2008* }\end{array}$ & AU** equivalent & Total A.Us & $\begin{array}{l}\text { Grazing on } \\
\text { rangelands }\end{array}$ & $\begin{array}{l}\text { AUs grazing on } \\
\text { rangelands }\end{array}$ \\
\hline Cattle & 31.8 & 1.0 & 31.80 & 5 & 1.59 \\
Buffalos & 29.0 & 1.5 & 43.50 & 5 & 2.18 \\
Sheep & 27.1 & 0.2 & 5.42 & 60 & 3.25 \\
Goats & 56.7 & 0.3 & 17.01 & 60 & 10.21 \\
Camels & 1.0 & 1.7 & 1.7 & 40 & 0.69 \\
Horses & 0.3 & 1.3 & 0.39 & 40 & 0.16 \\
Asses & 4.4 & 0.6 & 2.64 & 40 & 1.06 \\
Mules & 0.2 & 1.0 & 0.20 & 40 & 0.08
\end{tabular}

Total: 102.66

Total: 19.21

*Source: Pakistan Economic Survey 2007-2008 (GoP, 2008); **Animal unit = An A.U is taken as a young cow weighing about $425 \mathrm{~kg}$ and consuming nine $\mathrm{kg}$ of air-dry forage per day. 
is still possible by protection and proper utilisation while severely degraded rangelands may not return to their original state even when rested for a longer time and require heavy investment for rehabilitation (Sarfraz et al., 2012). Palatable shrubs species as well as traditional grasses are limited to simply in a few secured forest areas. Reasons behind rangeland degradation involve climate change leading to drought and also human factors causing the excess of natural resources.

Even more, the combination of each factor might be stated because the main reason for the world degradation of rangelands. The impacts of global warming with human challenges on the soil have a reduction of the soil nutrients, with a loss in water maintenance, which eventually results in breakdown in soil structure. Intensification of land usage with no appropriate management decrease efficiency, which might result in additional agricultural development in extra small regions. This expansion finally causes the soil erosion of huge swathes of rangeland.

Human factors contributing to rangeland degradation:

- Populations growth

- Market expansion

- Inappropriate policy initiatives

- Overgrazing

- Encroachment by subsistence farmers

- Collection of firewood

- Migratory herds

Conclusion and recommendations. The best way to improve the low and moderate degraded rangelands is to close the area to grazing. This results in replacement of poor forage and unpalatable grasses by more nutritious perennials. The most important activity in range improvements is increasing the productivity of forage through introduction of high yielding, palatable, forage species and their strains in suitable habitats. The increase in carrying capacity of the highly depleted tropical rangelands of Pakistan is possible through reseeding with promising species. To treat large areas, aerial reseeding is needed but unfortunately, economically and technically aerial seeding is not practiced in Pakistan (Kaul and Thalen, 1971).

Other measures are:

- Fencing

- Herding

- Control of weeds

- Use of fertilizers
On the basis of the above findings it is concluded that wide spread poverty lies in the mis-management of the rangelands. Majority of farmers of Pakistan are illiterate and have low income. Their small parcels of agriculture and pasture lands are not sufficient to meet the needs of their dependents and livestock. However, the excessive grazing is not a cause of accelerated erosion in their opinion. Most of them had constructed the walled terraces and water disposal drains to mitigate erosion on their lands but they face problems due to poor financial conditions. The farmers are not showing interest to convert their small agricultural productive lands to rangeland that's why most of them are not in a position to feed themselves as well as their livestocks.

In view of conclusion the following recommendations are suggestions:

1. There is a need to plant maximum number of fodder trees and ensure that they are looked after properly.

2. Animal grazing should be minimized in spring season when plants begin to grow.

3. The system can only be implemented if the local population understands the principles of grazing management and is ready to cooperate.

4. Avoid moving livestock from relatively immature to mature vegetation.

5. Focused control measures on sites with greatest potentials for producing desirable range forage: give least attention to sites with brush that will not respond economically to treatment.

6. The year before grasses are planted, establish forage or grain sorghum types in rows one to three feet apart, preferably in east-west rows at right angles to prevailing southerly and northerly winds that desiccate the grass seedbed or cause erosion.

7. To establish grass as an alternative to cultivated crops on highly productive farmland, plant single species or simple mixtures of warm-season tall grasses that respond efficiently to nitrogen fertilization, are palatable, have inherently high livestock carrying capacity, and resist encroachment by lessproductive vegetation.

8. Regulate stocking rates for optimum animal performance.

9. Remove livestock when necessary to prevent soil puddling during periods of high rainfall.

10. Introduction of improved management system should be applied to reduce the destruction of rangelands. Rotational grazing system would be better for this area. The area should be divided into 
different grazing blocks according to their potential and improvement programme should be advised for each block.

11. Where there is more fodder available than is needed, the zero grazing system can be combined with some grazing. The duration of grazing can be a few hours per day or even several days to weeks, depending on the climatic and users condition.

12. High quality seeds of nutritious grasses and legumes should be planted.

13. Protection of improved rangelands should be improvised after sowing or planting the grasses, legumes and fodder trees for some times for proper establishment and development.

14. Planting of fodder species after care is not up to the mark as indicated by the respondents which is one of the reasons for the failure. This is due to lack of proper supervision. It is suggested that participant farmers should be actively associated for supervision and protection.

15. All over the tract the ranges have been deteriorated, eroded throughout the plateau, so extensive reseeding, tuft planting and shrub/trees should be planted on priority basis.

16. As the ranges are mostly eroded and denude, so reseeding both artificial and natural is needed, so the Rast Rotation Grazing is the suitable one.

17. Rangelands controlled by the forest department should be strengthened with dedicated personnel and awarded fringe benefits. Requirements of these personnel should be exclusively for range management.

\section{References}

Afzal, J., Ahmed, M., Begum, I. 2008. Vision for Development of Rangelands In Pakistan - A Policy Perspective. Quarterly Science Vision, 14: 53-58.

Ahmad, S.S., Ehsan, H. 2012. Analyzing the herbaceous flora of Lohi Bher wildlife park under variable environmental stress. Pakistan Journalof Botany, 44: 11-14.

Ahmad, S., Islam, M. 2011. Rangeland productivity and improvement potential in highlands of Balochistan, Pakistan. In: Biomass-Detection, Production and Usage, M.D. Matovic (ed.), pp. 289-304, Rijeka, Croatia.

Ahmad, S., Islam, M., Bano, G., Aslam, S., Koukab, S. 2009. Seasonal variation in current season and dead biomass of Chrysopogon aucheri (Boiss) Stapf. and Cymbopogon jwarancusa (Jones) Schult in highland Balochistan, Pakistan. Pakistan Journal of Botany, 41: 519-527.

Ahmad, S., Call, C.A., Schupp, E.W. 2000. Regeneration ecology of Chrysopogon aucheri and Cymbopogon jwarancusa in upland Balochistan: 1. Morphology, viability and movement of seeds (spikelets). Pakistan Journal of Biological Science, 3: 18801883.

Aleem, A. 1980. Range management in Northern Areas. Pakistan Journal of Forestry, 30: 31-38.

Bano, G., Islam, M., Ahmad, S., Aslam, S., Koukab, S. 2009. Nutritive value of Chrysopogon aucheri (Boiss) Stapf. And Cymbopogon jwarancusa (Jones) Schult in highland Balochistan, Pakistan. Pakistan Journal of Botany, 41: 511-517.

FAO, 1987. Pakistan's experience in rangeland rehabilitation and improvement. FAO of the United Nations, pp. 70.

GOP, 2008. Pakistan Economic Survey 2007-08. pp. 32-33, Govt. of Pakistan. Finance Div., Economic Adviser's Wing, Islamabad, Pakistan.

Hussain, F., Durrani, M.J. 2007. Forage productivity of arid temperate Harboi rangeland, Kalat, Pakistan. Pakistan Journal of Botany, 39: 1455-1470.

Islam, M., Ahmad, S., Aslam, S., Athar, M. 2008. Mineral composition and antinutritional components of shrubs: Rangeland species from the upland Balochistan, Pakistan. Agriculture Conspectus Scientificus, 73: 27-35.

Kaul, R.N., Thalen, D.C.P. 1971. Range ecology at the Institute of Applied Researches in Natural Resources, Iraq. Nature and Resources, 7: 2-15.

Mahmood, K., Rodriguez, A. 1991. Marketing and processing of small ruminants in highlands of Balochistan. Research Report. International Center for Agriculture in the Dry Areas, pp. 14-19.

Malakand Social Forestry Project: A Practice in Social Forestry. 1988. pp. 48.

Sarfraz., Dogar, H., Farooq. 2012. Forage Production and Carrying Capacity Comparison Under Seeded \& Unseeded Conditions In Rakh Shadan Lund Range Land (Dera Ghazi Khan). Pakistan Journal of Forestry, 62: 27-32.

Umrani, A.P., English, P.R., Younie, D. 1995. Range land in Pakistan. Asian Livestock, Bangkok, Thailand, 3: 30-36. 